\title{
Perilaku Komunikasi Hiperpersonal Pasangan Muslim pada Online Cinta
}

\author{
Ellys Lestari Pambayun \\ Prodi Komunikasi Penyiaran Islam \\ Fakultas Dakwah Institut PTIQ Jakarta, Indonesia \\ ellyslestari@ptiq.ac.id
}

\begin{abstract}
Abstrak
Kajian tentang perilaku komunikasi hiperpersonal pasangan Muslim melalui online cinta ini berasal dari pengamatan fenomena aktivitas pengguna internet yang berbeda jenis kelamin yang berinteraksi secara sosial, intens, romantik, bahkan intim meski belum menikah. Terlepas dari adanya larangan agama Islam tentang pacaran, ditemukan masalah, bahwa chatting room pada facebook dan whastapp telah mengindikasikan hubungan cinta yang lebih mudah dan terbuka dibandingkan kehidupan nyata, seringkali tanpa sekat atau kaidah-kaidah agama, status sosial, pendidikan, perbedaan fisik, negara, status perkawinan, dan usia. Selain itu, online cinta telah membuat orang-orang mudah menemukan pasangan (jodo), baik seagama maupun tidak, dapat dijadikan media affair bagi pasangan yang kehidupan perkawinannya berantakan, dan menjadi media untuk berbuat tidak setia pada pasangan. Pendekatan yang digunakan adalah Hermeneutika Sosial, teori Komunikasi Hiperpersonal dan konsep relasi Islami. Metodologi yang digunakan metode communication mediated computer (CMC) melaui wawancara online pasangan online cinta dalam berbagai karakteristik dan pola interaksi atau komunikasi Hasil penelitian imenjelskan bahwa secara komunikasi hiperpesonal, pasangan muslim melalui cyberlovers pada facebook dan watsapp mengonstruksi presentasi diri, atribusi diri, dan intensifikasi komunikasi pada pasangannnya. Para pasangan Muslim ini dapat saling berperan sebagai pengirim yang selektif, namun agak kurang dapat mengontrol komunikasi yang tidak berbasis agama. Sebagai penerima pasangan kurang mampu menjadi penyeimbang dan saling menyesuaikan komunikasi mereka. Dalam saluran, para pasangan berkomunikasi secara asinkron dan sinkron di mana para informan saling mengirim "pesan intensif" atau terus menerus tanpa terbatas ruang dan waktu. Namun, sifat hubungan pasangan online ini belum sesuai dengan bingkai ta'aruf, khitbah, dan ghasiyah nau' yang terkandung dalam nilai-nilai Islam.
\end{abstract}

Kata kunci : perilaku, komunikasi, hiperpersoanal, online ,cinta

\begin{abstract}
The study of hyperpersonal communication behavior of Muslim couples through online love comes from observing the phenomenon of the activities of internet users of different sexes who interact socially, intensely, romance, even intimate even though they are not married. Despite the prohibition of Islamic religion about dating, problems have been found, that chat rooms on Facebook and Whastapp have indicated that love relationships are easier and more open than real life, often without barriers or religious norms, social status, education,
\end{abstract}


physical differences, state , marital status, and age. In addition, online love has made it easy for people to find a partner (jodo), whether religious or not, can be used as an affair media for couples whose marital life is in disarray, and a media for disloyal acts to their partners. The approach used is Social Hermeneutics, Hyperpersonal Communication theory and the concept of Islamic relations. The methodology used by the communication mediated computer $(\mathrm{CMC})$ method through online interviews of online couples in love in various characteristics and patterns of interaction or communication The results of the study suggest that in hyper-personal communication, Muslim couples through cyberlovers on Facebook and Watsapp construct self-presentation, self-attribution, and communication intensification. to his partner. These Muslim couples can play a role as selective senders, but they lack control over non-religious communication. As recipients, couples are less able to be balancing and adjusting their communication. In the channel, the pairs communicate asynchronously and synchronously where the informants send each other "intensive messages" or continuously without space and time. However, the nature of this online couple's relationship is not in accordance with the ta'aruf, khitbah and ghasiyah nau frame contained in Islamic values.

Keywords: behavior, communication, hyperpersoanal, online, love

\section{Pendahuluan}

Tak bisa dipungkiri bahwa internet menyediakan akses untuk mendapatkan cinta, bukan hanya pada pasangan seagama, tapi juga berbeda agama atau keyakinan. Melalui situs sosial yang sedang banyak digunakan masyarakat, masyarakat Muslim pun mencoba peruntungannya untuk mencari calon pasangan. Padahal, Al Bukhari menegaskan bahwa istilah pacaran sebenarnya tidak dikenal dalam Islam.Untuk istilah percintaan antara laki-laki dan perempuan pranikah, Islam mengenalkan istilah ' $t a$ ' $a r u f$ ' atau berkenalan kemudian 'khitbah' yang berarti meminang. ${ }^{1}$ Ketika seorang laki-laki menyukai seorang perempuan maka ia harus mengkhitbahnya dengan maksud akan menikahinya pada waktu dekat. Ada perbedaan antara pacaran dan khitbah. Pacaran belum tentu berkaitan dengan perencanaan pernikahan.

Namun, realitas yang tak terbantahkan bahwa pacaran merupakan perilaku yang sudah dianggap lazim dan bagian dari kehidupan manusia, khususnya remaja. Apalagi hubungan di era globalisasi yang diringin pesatnya perkembangan perangkat teknologi komunikasi seperti internet ini yang tanpa sekat dan ruang tak terbatas, sehingga memungkinkan hubungan dapat terjadi secara mudah dan cepat. Fenomena ini pernah dilaporkan CNN pada 2015, melalui survei terhadap 400 responden berusia 18-25 tahun, yang menelaskan bawa orang Indonesia tergolong aktif melakukan relasi dan berkenalan dengan lawan jenis secara daring : delapan dari 10 orang Indonesia berkenalan melalui jejaring internet. Perilaku virtual (hiperpersonal) ini meningkat tajam berdasarkan hasil survei yang dilakukan Badoo.com bahwa generasi milenial menghabiskan 10 jam untuk berkencan di layanan daring. Sedangkan penelitian tentang motivasi menggunakan aplikasi kencan dari Jajak Pendapat Aplikasi (Jakpat) pada 2017 terhadap 512 pengguna Tinder di

\footnotetext{
1 Jeffry Al Bukhari, Sekuntum Mawar Untuk Remaja. Jakarta : Pustaka Al-Mawardi.2006,hal.11
} 
Indonesia tujuan untuk mencari pasangan potensial (31,70\%). ${ }^{2}$

Cyberlovers, menurut Ann Casiman (2018) menjadi lingkungan yang sangat populer bagi para remaja di Afrika, selain di AS. Mereka terlibat dalam kelompok-kelompok kecil yang bertemu hampir setiap hari, untuk mengobrol, bermain, dan 'menunggu', sambil bermimpi bersama tentang masa depan yang lebih baik di tempat yang jauh. Persahabatan yang menemukan akar melalui pangkalan yang diberi nama seperti 'Chicago' atau 'Brooklyn', menuntun pada harapan dan cara-cara tindakan khusus yang untuk terlibat dengan kehidypan kota, dunia yang lebih luas dan milik mereka sendiri. Secara etnografis, para remaja membangun hubungan kedekatan, persahabatan dan kepercayaan, serta hak pilihan para remaja itu sendiri untuk menentukan pasangan. Internet sebagai media kencan ini mereka jadikan sebagai modalitas dengan berbagai cara, seringkali mengarah pada penipuan, persahabatan, dan cinta bergantung pada ikatan persahabatan lokal yang vital, yang ditentukan oleh kepercayaan, dari browser. Misalnya di Zongo, browsing membuka kemungkinan baru tetapi juga tantangan, dan mengikis sosialitas moral yang ada di antara remaja tersebut. ${ }^{3}$

Dari praobservasi yang dilakukan peneliti, berbagai opini menyatakan bahwa mereka lebih mengidealkan sebuah relasi yang "nyata" atau tidak bermedia, semisal komputer dengan berbagai aplikasi dan tawaran situs-situsnya. Pengalaman mereka menyatakan bahwa berbagai jenis cyberlovers seperti aplikasi layanan kencan daring seperti Tinder, Tantan, OKCupid, Badoo, hingga Matchmaker, pernah memberikan dampak buruk dan kekurangnyamanan lainnya bagi psikologis dan batin penggunanya, baik laki-laki maupun perempuan.

Demikian dengan hubungan cinta pasangan Muslim via internet yang saat ini sudah banyak dilakukan. Realitas "pacaran" di dunia maya yang telanjur merebak tanpa terbendung. Menurut Bright Side, Philipp Hergovich dan Josue Ortega dari Universitas Wina melaporkan hasil penelitian mereka bahwa pasangan yang bertemu melalui situs kencan online lebih mungkin berhasil ketika mereka ke jenjang pernikahan, daripada individu yang memulai hubungan dengan cara tradisional seperti bertemu di tempat kerja maupun kenal dari teman. ${ }^{4}$

Dalam praobservasi pada dua remaja di sebuah sekolah Islam di Jakarta mengungkapkan bahwa pacaran jarak jauh yang dilakukan dengan pasangannya memberi kenyamanan dan perasaan percaya yang berbeda, di banding dengan pengalaman saat berpacaran dengan pasangan sebelummnya saat di dunia nyata. Seperti pengakuan para santri Pondok Pesantren di Yogyakarta berdasarkan hasil penelitian Fhika Adina Sari (2016) yang melaporkan bahwa mahasiswa-mahasiswi santri memandang perilaku pacaran

\footnotetext{
2 https://ekspresionline.com/2019/05/18/relasi-romantis-maya-dan-ilusi-cinta-yang-nihil/

3 Ann Cassiman, Browsers and Phone Girls: The Intricate Socialities of Friendship, Trust and Cyberlove in Nima (Accra), Africa, The Journal of the International African Institute, Cambridge University Press, Volume

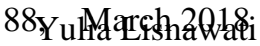

https://www.liputan6.com/citizen6/read/4173803/studi-pasangan-yang-bertemu-lewat-situs-kencan-diklaim-lebi h-langgeng 07 Februari 2020
} 
sebagai suatu proses yang wajar dijalani, baik jarak dekat maupun jauh (online relationship). Di mana hubungan jarak jauh ternyata lebih dapat bersifat terbuka kepada pasangan, yang penting tidak menabrak rambu-rambu agama. Pola hubungan para santri ini cenderung mengarah pada bentuk "pacaran berpahala" yaitu berhubungan dekat tapi tetap menjaga prinsip-prinsip Islam, karena makthtubah (pacar) masih berstatus ajnabiyyah (perempuan lain) bukan istri atau suami. ${ }^{5}$ Prinsip ini sebagaimana yang diatur dalam firman Allah SWT: "

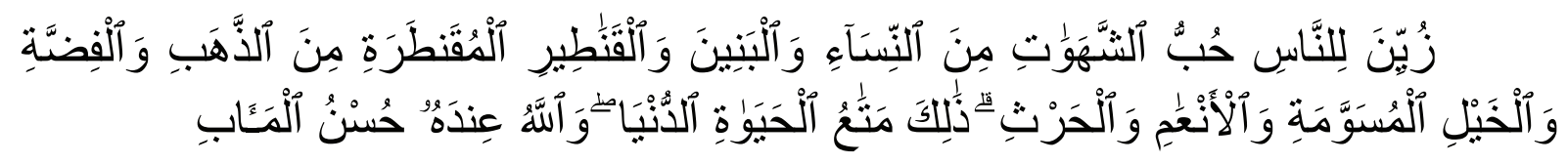

"Dijadikan indah pada (pandangan) manusia kecintaan kepada apa-apa yang diingini, yaitu: wanita-wanita, anak-anak, harta yang banyak dari jenis emas, perak, kuda pilihan, binatang-binatang ternak dan sawah ladang. Itulah kesenangan hidup di dunia dan di sisi Allah-lah tempat kembali yang baik (surga)" (QS. 3:14).

Art Ramirez, asisten profesor bidang komunikasi di Arizona State University menyatakan beberapa orang mungkin berpikir hubungan akan berjalan dengan baik jika memanfaatkan Facebook. Namun, seringkali kita melupakan kebutuhan 'obrolan kecil' yang berkualitas. Dalam Islam komunikasi yang efektif atau berkualitas disebut dengan qawlan balighan. Tidak dipungkiri, popularitas Facebook dan Twitter saat ini sangat tinggi. Situs peneliti internet Experian Hitwise mengatakan pada Januari lalu, Facebook memiliki bagian $12,46 \%$ dari keseluruhan trafik online Inggris. Jumlah itu menunjukkan sebanyak 2,4 miliar orang mangakses Facebook. Facebook juga diketahui memiliki 56\% total kunjungan. Facebook dan Twitter merupakan jejaring sosial paling populer di dunia Twitter menunjukkan pertumbungan sangat pesat sejak peluncuran pada 2006. Situs ini memiliki setidaknya 253 juta pengguna aktif setiap bulan, 85\% lebih tinggi dari jumlah di tahun lalu. 6

Penelitian ini bermaksud mengeksplorasi dan mendeskripsikan teks-teks dalam percakapan para pasangan online di cyberlovers untuk mendapatkan pemahaman mereka melalui Teori Hermeneutika Sosial. Sedangkan, Komunikasi Hiperpersonal (HC) difungsikan sebagai alat analisis untuk melihat perilaku komunikasi hiperpersonal pada daring cinta pada individu-individu yang memiliki hubungan dekat untuk menentukan pola hubungan mereka. Dan, communication mediated computer (CMC) dijadikan sebagai teori terapan dan metode penelitian sekaligus untuk menjelaskan bagaimana internet memediasi bentuk-bentuk dan perilaku komunikasi penggunanya, dalam hal ini para pasangan Muslim melalui aplikasi facebook dan WA.

Artikel ini akan menjawab beberapa pertanyaan sebagai berikut: 1 Makna komunikasi yang bagaimana yang terjadi dalam teks-teks (percakapan) via facebook dan WA pada pasangan muslim melalui online cinta? 2. Bagaimana tindakan dan perilaku

\footnotetext{
${ }^{5}$ Fhika Adina Sari. Gaya Pacaran Mahasiswa-Mahasiswi Santri Pondok Pesantren di Yogyakarta. Jurnal Sosiologi Pendidikan I. Universitas Negeri Yogyakarta. 2016, hal 3-4

${ }^{6}$ http://www.flickr.com/photos/34207237@N04/4315865952/ BSEO @2010,
} 
komunikasi hiperpersonal para pasangan Muslim melalui online cinta saat melakukan hubungan via facebook dan WA? Maka dari itu artikel ini mencoba untuk mengeksplorasi makna teks-teks (percakapan) yang terjadi via facebook dan WA pada pasangan Muslim online cinta. b. Untuk menganalisis tindakan dan perilaku komunikasi hiperpersonal para pasangan Muslim online cinta saat melakukan hubungan via facebook dan WA.

\section{Kerangka Teoretis}

\section{Tinjauan Pustaka}

Penelitian dari Rosenfeld. Michael J. (2017) tentang "Marriage, Choice, and Couplehood in the Age of the Internet" bermaksud meberikan penjelasan tentang teknologi Internet dan media sosial yang mempengaruhi kehidupan romantis manusia. Kritik terhadap efek Internet pada kehidupan sosial mengidentifikasikan gejala meningkatnya pilihan calon pasangan online sebagai sumber ketidakstabilan hubungan. Studi ini meneliti data longitudinal yang menunjukkan bahwa pertemuan online tidak memprediksi perpisahan pasangan. Pertemuan online (terutama melalui situs web kencan online) justru memprediksi transisi yang lebih cepat ke pernikahan untuk pasangan heteroseksual. Penelitian ini tidak mengukur efek kausal dari teknologi Internet pada usia suatu hubungan atau pembentukan pernikahan. Sebaliknya, penelitian ini lebih menyarankan bahwa teknologi atau Internet itu konsisten bersifat netral terhadap hubungan positif, bukan tentang terjadinya korelasi antara hubungan negatif antara Internet dan hubungan romantis. ${ }^{7}$

Pada penelitian Rang-An Shang, Yu-Chen Chen, dan Je-Wei Chang (2015) dengan judul "Individual Attachment Style, Self-disclosure, and How People Use Social Network" yang meneliti dampak gaya lampiran (attachment styles) individu teradap pengungkapan diri (self disclosure) dan perilaku pengguna di Facebook dalam rangka menalin relasi yang lebih dekat. Hasil survei online menunjukkan gaya lampiran individu memengaruhi posting dan perilaku mereka, kemauan untuk mengungkapkan diri, merespons, dan keterbukaan perilaku mereka. ${ }^{8}$

\section{Teori Hermeneutika Sosial}

Dalam penelitian tentang perilaku komunikasi pada pasangan Muslim melalui online cinta via internet ini peneliti lebih memilih teori hermeneutika sosial karena teori ini bertujuan untuk memahami bagaimana perilaku yang berada dalam situasi sosial yang

\footnotetext{
7 Rosenfeld. Michael J. "Marriage, Choice, and Couplehood in the Age of the Internet." Sociological Science 4, p. 490-510. June 2017

${ }^{8}$ Rang-An Shang, Yu-Chen Chen, \& Je-Wei Chang, "Individual Attachment Style, Self-disclosure, and How People Use Social Network", Multidisciplinary Social Networks Research in Communications in Computer and Information Science (CCIS), Volume 540, p. 49, August 2017
} 
diamati menginterpretasikan nasib mereka sendiri. Sebagaimana yang dijelaskan etnografer Cristine Hine (2000) bahwa teori hermeneutika sosial (social hermeneutic) berusaha memahami bagaimana peristiwa "dalam dunia makhluk asing dapat dipahami oleh makhluk hidup tersebut, bagaimana cara hidup mereka berkoheren, bermakna, dan bernilai bagi orang yang memengaruhinya" ${ }^{9}$ Konsep penting lainnya yang melekat dalam deskripsi ini adalah bahwa setiap teks, setiap produk interaksi sosial, seperti di internet (facebook dan WA) antara laki-laki dan perempuan dapat menjadi sumber pemahaman.

Ada pun secara paradigmatis, teori hermenetika sosial didasarkan pada ontologi, epistemologi, dan aksiologi yang dapat dijelaskan sebagai berikut:

Secara Ontologi : Teori hermeneutika menyatakan bahwa sesungguhnya tidak ada kenyataan sosial yang benar-benar "nyata" dan dapat "terukur", realitas tidak pernah akan dipahami kecuali dapat mempertimbangkan proses mental dan sosial yang tanpa henti mengonstruksi realitas tersebut". Dengan demikian, apa yang dapat dimengerti oleh pasangan Muslim melalui perilaku komunikasinya di cyberlovers didasarkan pada interpretasi mereka tentang apa yang mereka ketahui. ${ }^{10}$

Secara Epistemologi : Teori hermeneutika menyatakan bagaimana pengetahuan ditingkatkan, bersandar pada interaksi subjektif antar pengamat (para peneliti dan teoritikus) dengan komunitasnya. Dengan perkataan lain, pengetahuan tersebut bersifat lokal: yaitu spesifik pada interaksi pasanga Muslim secara online orang yang tahu dengan apa yang mereka ketahui.

Secara Aksiologi : Teori hermeneutika mempertimbangkan pengaruh peneliti dan nilai dari para teoretikus. ${ }^{11} \mathrm{Di}$ sini, peneliti tertarik untuk memahami interpretasi atau penciptaan makna para pasangan Muslim di online (facebook dan WA).

\section{Hyperpersonal Communication Theory}

Teori Komunikasi Hiperpersonal adalah menjelaskan tentang situasi komunikasi dengan perantara komputer yang mengarah pada pembentukan hubungan yang kuat. Walther (1996) mengemukakan tiga faktor yang cenderung menjadikan partner komunikasi via komuter lebih menarik dibandingkan dengan hubungan langsung, sebagai berikut: a. E-mail dan jenis komunikasi komputer lainnya memungkinkan presentasi diri (self presentation) yang sangat selektif, dengan lebih sedikit penampilan atau perilaku yang tidak diinginkan dibandingkan komunikasi langsung. b. Orang yang terlibat dalam komunikasi via komputer kadangkala mengalami proses atribusi yang berlebihan yang di dalamnya mereka membangun kesan stereotip tentang partner mereka. Kesan-kesan ini sering mengabaikan informasi negatif, seperti kesalahan cetak, kesalahan ketik, dan sebagainya. c.

9 Christine Hine. Virtual Ethnography. London, Thousand Oaks, New Delhi:SAGE Publications,2000

10 Norman K. Denzin dan Yvonna S. Lincoln. Qualitative Research. London : SAGE, 2011, hal. 16

11 Stanley J. Baran dan Denis K.Davis, Mass Communication Theory. USA. Wadsworth, 2009, hal 15-16). 
Ikatan intensifikasi bisa terjadi yang di dalamnya pesan-pesan positif dari seorang partner akan membangkitkan pesan-pesan positif dari rekan satunya. ${ }^{12}$

Ada pun Nugroho (2010) menjelaskan bahwa komunikasi hiperpersonal terjadi ketika individu menemukan bahwa mereka lebih suka dapat mengekspresikan diri mereka sendiri pada lingkungan mediation di bandingkan berhadap-hadapan secara langsung dalam berinteraksi. Komunikasi hiperpersonal didasarkan pada empat faktor : a. Faktor sumber : memiliki kontrol yang besar terhadap dirinya sendiri. b. Penerimanya : penerima dapat langsung menerima feedback yang tergantung pada pesan yang disampaikan. c. Channel : tidak sinkron. d. Feedback: timbal balik yang berlangsung secara kontinu atau terus menerus dalam waktu yang lama. ${ }^{13}$ Dalam penelitian ini Polkosky (2008) menegaskan tiga karakteristik dasar yang menjadikan pentingnya pembahasan keberadaan teknologi komunikasi yang disebut communication mediated computer (CMC). Pertama, memiliki definisi dan teori komunikasi interpersonal yang berbasis komputer. Kedua, interaksi atau subjek yang kompleks. Ketiga, kebiasaan-kebiasaan komunikasi yang berbeda dari komunikasi tatap muka. ${ }^{14}$

\section{Konsep Hubungan Pacaran dalam Islam}

Konsep Islam secara tegas mengatur hubungan sepasang remaja sebelum menikah yang disebut pacaran melalui Surah Al-Imaran ayat 14. Dalam untaian ayat tersebut dijabarkan bahwa dalam diri manusia memang telah ditanam benih-benih cintan dan kasih sayang yang suatu waktu bisa tumbuh seketika saat menemukan kecocokan jiwa. Cinta dalam Islam tidak dilarang karena ia berada di luar wilayah kendali manusia bahkan cintan merupakan anugerah yang harus di syukuri dengan mengekspresikan dan membinanya sesuai norma-etik syariat.

Jadi, pacaran dapat diartikan sebagai ajang untuk saling meneganal untuk mengerahui karakter masing-masing pasangan. ${ }^{15}$ Fenomena yang timbul dari tingkatan-tingkatan cinta yang ada akan menimbulkan efek yang berbeda. Pertama, pada fenomena tingkatan cinta yang tertinggi, maka akan membuat seseorag dalam hidupnya untuk selalu mendahulukan cinta kepada Allah Swt, Rasul-Nya dan jihad dijalan-Nya. Dalam kehidupannya sehari-sehari tidak ada orientasi selain kepada Sang Khalik. Dia akan selalu merasa yakin bahwa segala sesuatu yg telah Allah Swttetapkan adalah yg terbaik bagi manusia. Bahwa Dia lebih mengetahui daripada makhluk-Nya. Kemudian, bagi seseorang yang sudah merasakan nikmatnya iman, maka dia akan selalu meneladani kepribadian

12 Werner J. Severin \& James. W. Tankard, Jr. Communication Theories:Origins, Methods, and Use in Mass Media. USA. Addison Wesley Longman. Inc, 2001, hal.462

13 Agoeng Nugroho, Teknologi Komunikasi. Cetakan Ke-1. Yogyakarta: Graha Ilmu. 2010, hal. 32

14 Melanie D.Polkosky. Understanding Social Media from the Media Ecological Perspective dalam Konijn,Elly A., Utz, Sonja., Tanis, Martin, and Barnes, Susan B. Mediated Interpersonal Communication. New York: Routledge, 2008, p.396

15 Abu Al Ghifari, Pacaran Yang Islami Adakah?. Bandung : Mujahid Press, 2003, hal 20 
Rasulluh saw, mencintai kekasih Allah ini, kemudian dia juga akan mencintai jihad dijalanNya. Bagkan, akan berjuang dengan segala apa yang dia miliki. Kedua, Adapun dampak yang disebabkan oleh cinta tingkat menengah dalam membentuk karakter individu, keluarga, dan masyarakat telah amat nyata. Jika tidak Allah ciptakan cinta pada suami -istri maka tidak akan tercipta keluarga, tidak akan lahir anak-cucu, tidak akan terjadi proses mengasuh, mendidik dan memelihara anak.Jika tidak Allah ciptakan cinta pada anak, niscaya dalam jiwanya tidak akan ada semangat kekeluargaan, tidak akan kokoh ikatan kekeluragannnya, tidak akan mengasihi saudaranya. Jika tidak Allah tanamkan rasa cinta pada manusia maka, tidak akan tercipta hubungan sosial antara bangsa yang dibangun atas prinsip ta'aruf (saling mengenal).Dengan demikian cinta tingkat menengah ini amat penting untuk menciptakan kemashalatan pribadi dan keluarga khususnya dan untuk merealisasikan kemaslahatan antar bangsa dan seluruh ummat manusia pada umumnya. Ketiga, Fenomena Cinta tingkat rendah. Cinta jenis ini ada beberapa macam: Mencintai thougut dan sesembahan selain Allah, seperti menyembah manusia, batu dan sebabainya, menjalin tali kasih kepada musuh-musuh Allah, mengumbar syahwat dan berkubang dalam lumpur kekejian dan kehinaan, mencintai ayah, ibu, anak, istri, suami, keluarga, karir, tanah air melebihi cintanya kepada Allah, Rasul-Nya dan Jihad dijalan-Nya. Islam denga universal ajarannya telah mengatur seluruh hubungan manusia baik secara vertikal (hablun min Allaahi) maupun horisontal (hablun min An Naasi) tak terkecuali hubungan sepasang anak manusia yang sedang dirundung asmara. Firman Nya:

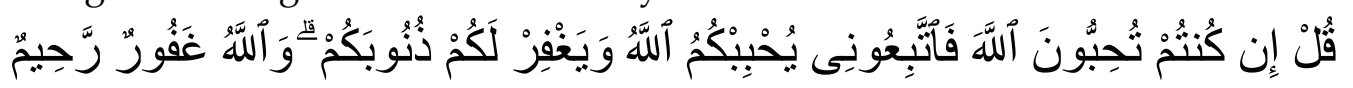

"Jika kalian (benar-benar) mencintai Allah, maka ikutilah aku, niscaya, Allah mengasihi dan mengampuni dosa-dosa kalian.' Allah maha pengampun lagi maha penyayang." ( Q.S. Ali 'Imran 3:31)

Dalam agama Islam diajarkan bahwa perasaan cinta ditujukan semata mata kepada sang pencipta, sehingga cinta kepada-Nya jauh melebihi cinta pada sesama makhluknya.Justru, cinta pada makhluknya dicurahkan semata-mata karena mencintai-Nya. firman Allah SWT dalam QS Al Baqarah 165:

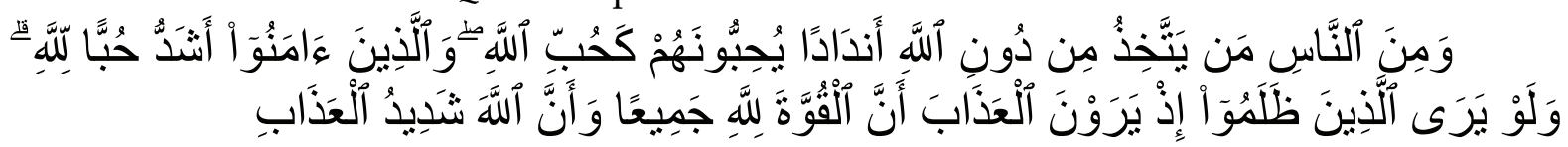

"Dan di antara manusia ada orang-orang yang menyembah tandingan-tandingan selain Allah; merekamencintainya sebagaimana mereka mencintai Allah. Adapun orang-orang yang beriman amat sangat cintanya kepada Allah."

Allah menyampaikan mengenai perbedaan dan garis pemisah antara orang-orang yang beriman dengan yang tidak beriman melalu indikator perasaan cintanya.

Istilah pacaran secara harfiyah tidak dikenal dalam Islam, karena konotasi dari kata-kata ini lebih mengarah pada hubungan pra-nikah yang lebih intim dari sekedar media saling mengenal. Islam menciptakan aturan yang sangat indah dalam mengatur hubungan lawan jenis yang sedang yang sedang jatuh cinta yaitu dengan konsep khitbah. Khitbah adalah sebuah konsep 'pacaran berpahala' dari dispensasi agama sebagai media yang legal bagi 
hubungan lawan jenis untuk saling mengenal sebelum memutuskan menjalin hubungan suami-istri. Konsep hubungan ini sangat dianjurkan bagi seorang yang telah menaruh hati kepada lawan jenis dan bermaksud untuk menikah akan tetapi hubungan ini harus tetap terbingkai dalam nilai-nilai keshalehan sehingga kedekatan hubungan yang bisa menimbulkan potensi fitnah berarti sudah diluar konsep ini. Sedemikian sakralnya makna pernikahan maka khitbah merupakan konsep urgen untuk menjembatani kemungkinan akan terjadinya kekecewaan di kedua belah pihak sebelum terjadi ikrar nikah. Lantaran proporsi fundamental khitbah hanya sebagai langkah yang merupakan sarana mengenali maka legalitas kedekatan hubungan dalam konsep ini hanya sebatas memandang wajah dan tahap saling dan telapak tangan karena rahasia fisik dan kepribadian seseorang sudah bisa dimonitor dan di sensor melalui aura wajah dan telapak tangan ${ }^{16}$. Berikut beberapa hadits Nabi saw yang memperkenankan melihat perempuan yang dikhitbahi dalam batas-batas tertentu : "Seorang perempuan datang menemui Rasulullah SAW lalu berkata: "Wahai Rasulullah, saya datang untuk menyerahkan diri saya kepada Anda! Rasulpun mengangkat pandangan kepadanya dan mengamatinya dengan saksama. Kemudian beliau menundukkan pandangan. Mengertilah wanita itu bahwa RasulullahSAW tidak berminat kepada dirinya, maka iapun duduk. Kemudian bangkitlah seorang lelaki dari sahabat beliau dan berkata: "Wahai Rasulullah, jika Anda tidak berminat maka nikahkanlah ia kepada saya" (H.R Al-Bukhari, Muslim dan An-Nasa'i) Dalam hadis lainnya:

"Jika salah seorang dari kamu meminang seorang wanita maka bila ia bisa melihat sesuatu daripadanya yang dapat mendorong untuk menikahinya hendaklah ia melakukannya." (H.R

Abu Dawud dan Al-Hakim)

Lebih dari itu dalam "Pacaran Berpahala" ini juga diperkenankan duduk dan berkomunikasi bersama sepanjang tidak sampai bernuansa khalwah (berduaan), seperti dengan disertakan pihak ketiga yang bisa melindungi dari fitnah karena makhtubah (baca pacar) bagaimanapun masih berstatus ajnabiyyah (wanita lain) yang sedikitpun belum berlaku hukum suami-istri. ${ }^{17}$

Orang yang beriman akan memberikan porsi, intensitas, dan kedalaman cintanya yang jauh lebih besar padaAllah. Sedangkan orang yang tidak beriman akan memberikannya justru kepada selain Allah, yaitu pada makhluk, harta, atau kekuasaan. Cinta dalam Islam terbagi dalam tingkatan-tingkatan, Adapun dasar tentang tingkatan cinta dalam Islam ${ }^{18}$, adalah firman Allah :

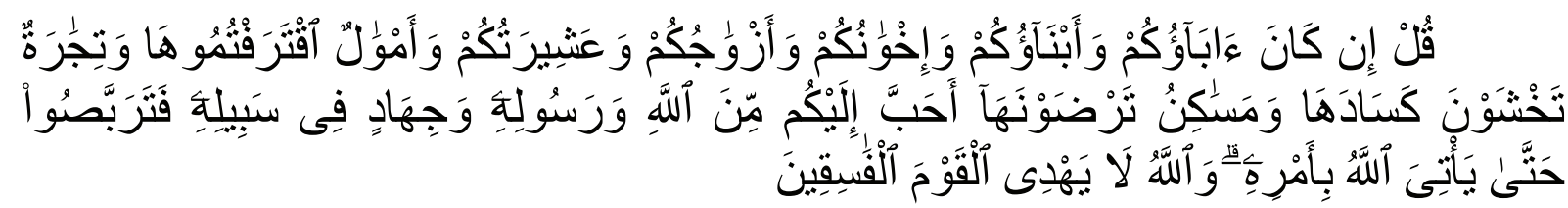

"Jika bapak-bapak, anak-anak, saudara-saudara, pasangan-pasangan, dan kaum keluarga kalian, harta kekayaan yang kalian usahakan, perniagaan yg kalian khawatirkan

\footnotetext{
16 Jefri Al Bukhari, Sekuntum Mawar Untuk Remaja, hal. 12

17 Abu Al Ghifari. Pacaran Yang Islami Adakah?, hal 20

18 Abu Al Ghifari, Pacaran Yang Islami Adakah?, hal. 21
} 
kerugiannya, dan rumah-rumah tempat tinggal yang kalian sukai, lebih kalian cintai daripada Allah, Rasul-Nya dan (daripada) jihad di jalanNYa, maka tunggulah sampai Allah mendatangkan siksaNya. Allah tidak memberi petunjuk kepada orang-orang yang fasik" (QS. 9 (At Taubah): 24).

Cinta pada tingkat tertinggi adalah cinta kepada Allah, Rasulnya dan jihad didalamnya. Cinta pada tingkatan menengah adalah cinta terhadap orang tua,anak, keluarga, pasangan dan saudara. Adapun cinta pada tingkatan terendah adalah cinta yang lebih mengutamakan terhadap harta, keluarga melainkan cintanya terhadap Allah, rasul-Nya dan jihad didalamnya.

\section{Metode Penelitian}

Sesuai dengan tujuan penelitian mengenai kajian communication mediated computer pada perilaku komunikasi hiperpersonal pasangan Muslim online cinta di facebook dan wa, maka metode penelitian yag digunakan adalah metode penelitian kualitatif. Di mana menurut Pambayun (2013) metode Communication Mediared Computer (CMC) hanya berusaha mengumpulkan data dari latar alamiah (facebook dan WA), di mana interaksi yang terjadi melalui jaringan komputer pada dasarnya diwakili dengan teks yang berbasis interaksi ${ }^{19}$. Subjek Penelitian : Subjek atau partisipan penelitian adalah para pasangan Muslim yang melakukan online cinta di internet seperti facebook. Dengan rentang usia mulai dari 18 tahun sampai dengan 40 tahun. Unit Analisis : Penelitian ini unit analisisnya adalah 5 (lima) percakapan berbeda pasangan tentang cinta atau hubungan dekat secara online, di mana mereka terdiri dari dua pasangan mahasiswa dan satu pasangan karyawan yang seagama (Islam) sebuah perusahaan swasta melalui facebook dan WA. Tahap Pengumpulan Data : Observasi secara online, wawancara online, dan menganalisis dokumen atau teks. Peneliti mengobservasi untuk melacak beberapa percakapan secara chatting atau online tentang pesan-pesan cinta yang dilakukan oleh para pasangan. Analisis Data : Analisis bersifat tematis dimulai dengan mengkaji teks atau percakapan di facebook dan WA secara chatting dan wawancara online pada para pasangan online cinta. Teknik Keabsahan Data: Dalam penelitian ini menggunakan teknik irtual atau siber melalui online yang dianggap sesuai dalam mengajukan cara-cara untuk mengonfirmasi dan memverifikasi komunikasi dan interaksi pasangan Muslim di internet (facebook dan WA) pada narasumber (subjek penelitian) dan para pemerhati atau pakar komunikasi ${ }^{20}$.

\section{Analisis dan Pembahasan Penelitian}

\section{Analisis Penelitian}

Dalam penelitian ini telah berhasil menghimpun data berupa teks, informasi atau keterangan yang sangat berguna dari para pasangan Muslim melalui online cinta dari para key informan yaitu HS (karyawan swasta), MFI (Mahasiswa), dan JA (mahasiswa) untuk

19 Ellys Lestari Pambayun, One Stop Research Qualitative Methodology in Communication. Jakarta : Lentera Cendekia,2013, hal.501

20 Nasrullah, Teori dan Riset Media Siber (Cybermedia), Jakarta : Kencana Prenada Media 2014 
mengeksplorasi realitas permasalahan krusial tentang internet dengan situs atau media sosialnya seperti facebook dan WA. Khususnya karakteristik dan perilaku komunikasi para informan dalam membangun dan mengelola hubungan dengan pasangan cinta mereka didasarkan kaidah-kaidah Islam yang mereka yakini, yang dapat dijelaskan sebagai berikut:

Dalam penelitian ini teori hermeneutika sosial digunakan adalah untuk memahami perilaku komunikasi pasangan online cinta melalui penafsiran sistematis terhadap teks-teks atau chatingan yang HS, JA, dan MFI lakukan di facebook dan WA dalam kurun waktu antara bulan Desember 2018 sampai Oktober 2019.

Melalui Teori Komunikasi Hiperpersonal ini peneliti akan menjelaskan tentang situasi komunikasi para pasangan Muslim melalui online cinta di facebook dan WA yaitu MIF, HS, dan JA yang mengindikasikan pada "pembentukan hubungan yang kuat", yang mengindikasikan bahwa mereka memang memiliki hubungan yang khusus atau “berpacaran" melalui teks-teks yang dituliskan pada media sosial dan ponsel (WA) yang mengucapkan sapaan-sapaan atau sebutan-sebutan "yang (sayang)", "cin (cinta)", "beb (babe)" bahkan "mami-papi" yang semua teks ini diperkuat dengan hasil pengakuan mereka pada wawancara online yang menyatakan bahwa hubungan mereka terbentuk melalui kontak di facebook (HS dan JA). Ada pun, MIF-AF menjalin hubungan melalui interaksi intens mereka di lingkungan kampus dan diseling dengan medsos atau WA sebagai upaya untuk memelihara relasi mereka. Sedangkan dalam pandangan Islam, komunikasi hioerpersonal yang dijalani pasangan ini menunjukkan bukan berkategori "pacaran berpahala" karena cenderung berkomunikasi dengan situasia khalwah (berduaan), tanpa disertakan pihak ketiga yang bisa melindungi dari fitnah.

Sedangkan dalam analisis hubungan dalam Islam, komunikasi hiperpersonal pasangan ini melalui teks-teksnya menunjukan fenomena cinta tingkat rendah karena. Jalinan cinta yang terjadi di antara pasangan Muslim ini lebih pada hubungan horisontal (habliminnanas) saja tanpa melibatkan Allah SWT sebagai tujuannya.

Dalam realitas ini, para pasangan tampaknya pada awal hubungan di medsos dan posel (facebook dan WA) membangun harapan yang netral atau non-intim, yang disebut dengan harapan pra-interaksional (pre-interactional expectation), artinya melakukan hubungan didasarkan pada keingintahuan dan interaksi yang ditunjang oleh kemampuan interaksi mereka pada dunia maya sebagai komunikator sebelum memulai hubungan atau percakapan yang intens. Bila dikorelasikan dengan hasil penelitian mengenai perilaku komunikasi para pasangan ini mereka tidak selalu mengetahui apa yang dibutuhkan, diinginkan untuk memasuki dan mempertahankan hubungan atau sebuah percakapan yag intim.Melalui medsos tersebut para pasangan dapat dengan mudah saling menghubungi, mengobrol intim dengan pasangan yang berada di luar negeri (Hongkong, Jakarta) bahkan mengirim kata-kata mesra sebanyak yang mereka mau tanpa takut dikenai biaya yang mahal atau pun waktu pengiriman yang lama. Secara Islam, perilaku komunikasi yang mengarah cinta antar pasangah Muslim ini sebagai kodrat atau fitrah yang ditanamkan Allah SWT suatu waktu bisa tumbuh seketika saat menemukan kecocokan jiwa. Cinta dalam Islam tidak dilarang karena ia berada di luar wilayah kendali manusia bahkan cintan merupakan 
anugerah yang harus disyukuri dengan mengekspresikan dan membinanya sesuai norma-etik syariat.

Terdapat tiga faktor yang cenderung menjadikan partner komunikasi via internet (facebook dan WA) lebih menarik dibandingkan dengan hubungan langsung. Pertama, para pasangan di facebook dan WA, dalam penelitian ini tampaknya memungkinkan "presentasi diri" (self presentation) yang sangat selektif, dengan lebih sedikit dapat menjaga penampilan atau perilaku komunikasi yang tidak diinginkan dibandingkan dengan komunikasi langsung. Selain itu, demi terjaganya hubungan asmara di antara mereka dan sangat membantu para pasangan yang tidak terlalu terampil berbicara, sulit mengekspresikan emosional, seperti yang diungkapkan HS, dan JA yang seringkali kehabisan kata dalam mempresentasikan diri di WA atau facebook. Melalui pesan teks tersebut mereka bisa menceritakan pengalamannya secara terkonsep dan lebih detail. Lebih dari itu, mereka juga dapat mempresentasikan diri melalui gamba-gambarr untuk lebih memperkuat ceritanya dan memiliki dokumentasi pengalamannya sehari-hari. Dalam Islam, hubungan "dekat" ini pasangan Muslim belum mengikuti konsep khitbah, sebagai hubungan lawan jenis yang berbingkai kesalehan karena hubungan mereka yang dekat meski via medsos tetap saja bisa menimbulkan potensi fitnah. Hubungan dalam pasangan ini pun sangat intens dengan bebas melepas kata-kata dan kemesraan melalui berbagai ekspresi tanpa sekat dan berprinsip jelas pada Al-Qur'an.

Kedua, pasangan online cinta yang terlibat dalam komunikasi via facebook ini kadangkala mengalami "proses atribusi yang berlebihan" yang di dalamnya mereka membangun kesan stereotip tentang partner mereka. Dari hasil analisis penelitian pasangan online ini seringkali melakukan sikap-sikap tidak biasa atau berlebihan atas percakapan dan peristiwa yang terjadi, seperti JA-JN, MIF-AF yang menuliskan kata-kata penuh perasaan secara berulang, dan HS-RWC dengan kata-kata mengandung peringatan yang keras dan sedikit ancaman. Hanya saja keintiman yang terjalin belum tentu bersesuaian antara yang terjadi dalam realitas dunia maya (hiperrealitas) dengan realitas yang sesungguhnya. Apabila dalam komunikasi interpersonal keintiman yang terjalin itu benar-benar nyata dan empirik, dalam komunikasi hiperpersonal hal itu lebih bersifat semu dan cenderung dilebih-lebihkan. Realitas tersebut tidak sejalan dengan konsep Islam yang lebih menekankan bahwa orang yang beriman akan memberikan porsi, intensitas, dan kedalaman cintanya yang jauh lebih besar padaAllah. Sedangkan orang yang tidak beriman akan memberikannya justru kepada selain Allah, yaitu pada makhluk, pasangan, atau orang-orang yang dicintainya.

Ketiga, ikatan intensifikasi pada pasangan online cinta bisa terjadi yang di dalamnya pesan-pesan positif secara personal dan formal dari seorang partner akan membangkitkan dan memengaruhi pasangannya tersbut, seperti yang terungkap dari online para informan berikut ini: Sejatinya, semakin akrab dua orang yang menjalin hubungan, maka proses peniruan, persuasif, dan sikap afeksi pun lebih dominan dibandingkan dengan sikap-sikap formalitas dan impersonal. Sehingga, pesan positif atau pun negatif akan lebih mudah merasuk pada psikologis pasangan tersebut. Ini terlihat pada teks yang diungkapkan para 
pasangan cinta. Misalnya, pasangan JA-JN dan MIF-AF yang saling mengingatkan untuk salat atau ibadah lainnya. Begitu pun, HS-RWC saling mengajak untuk membantu sahabatnya untuk menemukan pasangan. Menurut konsep Islam, komunikasi positif antara pasangan online ini menunjukkan "dampak cinta tingkat menengah" yang dapat membentuk karakter pasangan secara nyata yang menuju pada bentuk-bentuk prose perilaku menjaga, mengasuh, mendidik dan memelihara pasangan masing-masing, meski belum menjadi suami istri yang dibangun atas prinsip ta'aruf (saling mengenal). Sedangkan untuk pesan negatif, pasangan ini pun saling membumbui dengan perselisihan, kecemburuan, kekecewaan, bahkan ajakan untuk bersentuhan juga hubungan intim, secara Islam ini menunjukkan adanya sikap yang menjauhkan diri dari "hubungan berpahala", bahkan dibenci Allah SWT.

Pada komunikasi hiperpersonal pasangan online cinta berpendapat mereka merasa lebih menyukai lingkungan mediation untuk mengekspresikan diri mereka sebagaimana mereka berhadap-hadapan secara langsung dalam berinteraksi, karena didasarkan pada empat faktor, yaitu : Pertama, sumber, yaitu pasangan online lebih memiliki kontrol yang besar terhadap dirinya sendiri, seperti yang diungkapkan HS, MIF, dan JA berikut ini. Sebagai pengirim bisa melakukan "sensor" pada apa yang ingin dia sampaikan. Misalnya, ketika JA sedang membutuhkan semangat dan menginginkan pasangannya (JN) mengetahui perasaannya melalui kode-kode atau simbol-simbol (emoticon dan teks) yang hanya dimengerti pasangannya, maka pasangannya akan segera memahaminya tanpa harus mengatakannya dengan jelas. Begitu juga, ketika HS menyebutkan "maa (mama)" pada pacar (bukan istri), maka pasangan perempuannya pun tidak menolaknya, karena itu adalah kode komunikasi mereka. Kedua, penerimanya, para pasangan juga berperan sebagai penerima pesan selain menjadi pengirim pesan. Posisi merek bisa bergantian, tergantung pada saat siapa yang sedang menyampaikan pesan sehingga terlihat dapat mengukur kualitas pasangannya. Misalnya, ketika JN ingin mengetahui perasaan JA, JN tinggal melihat tulisan di WA JA kegiatan dan gambar-gambar, status-status atau kata-kata apa yang sering ditampilkan di personal profile JA atau di facebook-nya. Ketiga, channel, artinya saluran tidak sinkron atau para pasangan ini dapat saja menggunakan berbagai bentuk media dalam situs yang sama, seperti yang dilakukan HS, MIF dan JA dengan pasangan masing-masing, di mana HS berkomunikasi dengan pasangan menggunakan Wa, sedangkan pasangan perempuannya menggunakan Android atau laptop. Namun, dalam medsos yang sama yaitu facebook atau WA. Proses komunikasi online di antara pasangan ini pun lebih berjalan secara bersamaan atau real time, atau ini disebut komunikasi sinkron (syncrhonous communication), misalnya JA-JN dan MIF-AF yang berkomunikasi dengan waktu respons hanya dalam hitungan menit atau detik. Ini menunjukkan bahwa feedback yang terjadi di antara mereka bersifat langsung. Pada komunikasi yang para informan lakukan pun bersifat pesan informal menyerupai bahasa percakapan sehari-hari. Sedangkan, komunikasi yang dilakukan HS-RWC lebh bersifat komunikasi asinkron (assynchronous communication) di mana proses interaksi yang terjadi di antara mereka terdapat tenggang waktu yang signifikan. Ini dimaksudkan agar pesan yang disampaikan bisa lebih terencana 
dan terkonsep, meski komunikasi hanya terbatas kalimat pendek. Keempat, adanya feedback di mana dalam hubungan para pasangan online cinta ini mendapatkan timbal balik yang berlangsung secara kontinu atau terus menerus dalam waktu yang lama, dan mengindikasikan bahwa umpan balik mereka mengarah pada "perputaran intensif" di mana konfirmasi pesan dari tiap perilaku komunikasi pasangan cinta ternyata dapat menguatkan perilaku masing-masing. Misalnya, pesan yang disampaikan MIF pada AF untuk segera bangun untuk segera melakukan aktivitas pada hari itu. Sedangkan, JA kepada JN memberikan pesan intensif untuk menjaga kesehatan untuk selalu melakukan gym. Begitu pula, pesan yang disampaikan HS kepada RWC adalah menginformasikan keadaan kesehatannya. Penguatan perilaku komunikasi ini berimplikasi pada dorongan semangat dan motivasi di antara pasangan.

Pendekatan Islam pada proses komunikasi hipperpersonal melalui unsur-unsurnya seperti sumber, pengirim, penerima, saluran, dan timbal balik ini merupakan indikasi belum adanya sikap ghrarizah nau' di mana masing-masing pasangan memiliki rasa kasih sayang, rasa nyaman, yang kemudian terdorong ingin saling memiliki yang tercipta hanya karena ingin mengabdi dan berserk ah pada Sang Khalik, bukan atas dasar syahwat apalagi sekedar game people play (maksiat). Pasangan online ini meskipun menjalani hubungan dan menginginkan hubungan yang lebih jauh dengan cara yang baik (JA, MF), tapi terdapat juga teks-teks yang tercatat komunikasi mereka cenderung "mengarah" pada hubungan yang dilarang agama Islam (HS).

\section{Pembahasan Penelitian}

Hasil penelitian ini membahas salah satu pendekatan yang Joseph Walther sebut sebagai komunikasi hiperpersonal (hyperpersonal communication) yaitu komunikasi yang terjadi ketika sesorang merasa nyaman untuk mengekspresikan diri mereka sendiri dalam saluran komunikasi melalui media seperti internet daripada komunikasi langsung. Internet khsusus facebook dan WA yang memfasilitasi komunikasi (khususnya pasangan cinta) yang menjadi fokus penelitian ini, menunjukkan bahwa media baru ini telah mampu menjadi ruang bagi para pasanga cinta untuk berkomunikasi secara intim dan personal tanpa dibatasi waktu.

Dalam penelitian ini mengungkapkan bahwa facebook dan WA dapat menjadi media lebih dari sekedar perangkat yang mampu mefasilitasi kemudahan dan berharga murah, tapi juga sebagai saluran untuk membangun self presentation, atribusi, dan intensifikasi komunikasi pada para pasangan Muslim dalam online cinta. Terungkap melalui penelitian ini bahwa para informan dalam chatting room dan WA ini memang memiliki hubungan yang khusus atau intim, bukan hubungan impersonal dan profesional. Ini terungkap dari teks dan pengakuan wawancara online di mana ungkapan-ungkapan dengan menggunakan sebutan-sebutan "sayang" dan "cinta", "ingin memelukmu", "ingin menciummu", bahkan "ingin berhubungan seks", dan ekspresi cinta lainnya (marah, tertawa, sedih, bingung, dan sebainya) disertai konflik-konflik sangat dominan terbaca. 
Faktor pengirim, penerima, saluran, dan feedback berwarna personal relations. Pertama, faktor pengirim, yaitu si HS, JA, dan MIF terlihat memegang kendali bagaimana menampilkan diri sendiri terhadap pasangannya. Jadi, mereka dapat secara selektif memilih apa yang akan diperlihatkan kepada pasangan mengenai dirinya. Kedua, faktor penerima, di sini terlihat dapat mengukur kualitas pasangannya di dalam komunikasi hiperpersonal, terbukti dengan kemampuan mereka dalammengontrol, mengimbangi atau menyesuaikan pola komunikasi atau pesan yang ditransmisikan pasangan mereka. Ketiga, faktor saluran pesan yang ditransmisikan para informan tersebut melalui facebook dan bbm tidak hanya menembus ruang tetapi juga waktu. Kapan saja, di mana aaja, dan dalam keadaan apa pun para pasangan ini selalu intens berkomunikasi, baik secara komunikasi sinkron atau dalam waktu bersamaan dan feedback yag langsung maupun komunikasi asinkron atau degan feedback yang tertunda. Terakhir, umpan balik yang dilakukan para informan dengan para pasangan cinta mereka cenderung mengarah pada "perputaran intensif" di mana konfirmasi pesan dari tiap perilaku komunikasi dapat menguatkan perilaku masing-masing. Sedangkan, dalam konsep hubungan lawan jenis secara Islam, komunikasi hiperpersonal yang duilakukan pasangan online ini cendeung belum memenuhi kaidah-kaidah atau syariat sebagai mana termaktub pada Al-Qur'an dan hadist dengan indikasi tidak terjadinya taa'ruf, khitbah, dan gharizah nau' yang menegaskan aturan-aturan yang indah, nyaman, dan berpahala dalam berhubungan dengan lawan jenis.

\section{Kesimpulan}

Penelitian dengan menggunakan paradigma hermeneutika sosial dengan salah satu pendekatannya yaitu komunikasi hiperpersonal pada facebook dan WA yang dilakukan para pasangan online cinta ini berhasil mengungkap perilaku komunikasi melalui teks-teks yang dituliskan para informan tentang hubungan personal atau intim para informan dengan para pasangan mereka. Perilaku komunikasi yang tampak seperti presentasi diri, atribusi yang berlebihan, dan intensifikasi komunikasi para pasangan ini. Ada pun faktor pengirim para informan lebih selektif dalam menampilkan diri dan berkomunikasi. Pada faktor penerima, para informan lebih mampu mengukur, mengontrol, dan mengimbangi perilaku komunikasi pasangan mereka. Pada faktor saluran, para informan cenderung berkomunikasi secara sinkron dan asinkron. Dan, pada feedback informan menunjukan pada sifat pesan intensif, artinya komunikasi mereka berlanjut tanpa terbatas ruang dan waktu.

Selain, itu dalam konteks komunikasi hiperpersonal tampaknya peran internet, khususnya facebook dan WA sebagai second age medium ini bagi para pasangan online cinta masih kurang dimanfaatkan untuk berwacana kritis dan transformatif dan Islami, artinya realitas dominasi percakapan masih seputar cinta, perasaan, dan perhatian yang berlebih dengan indikasi frekuensi pesan dan komentar masih berada pada "intimasi", tidak diarahkan untuk membangun suatu hubungan religiousitas Islam dalam upoaya mendekatkan diri pada Sang Maha Pemberi cinta kasih. Pesan motivasi, substansi untuk 
hidup lebih dekat dengan Allah SWT hanya dalam beberapa waktu dari rangkaian komunikasi yang mereka lakukan dan lebih banyak sebagai pelengkap.

\section{Daftar Pusataka}

Al Ghifari, Abu. Pacaran Yang Islami Adakah?. Bandung : Mujahid Press. 2003

Al Bukhari, Jefri. Sekuntum Mawar Untuk Remaja. Jakarta : Pustaka Al-Mawardi. 2006

Baran, Stanley J. dan Davis, Denis K, Mass Communication Theory. USA. Wadsworth, 2009.

Cassman Ann, Browsers and Phone Girls: The Intricate Socialities of Friendship, Trust and Cyberlove

in Nima (Accra), Africa, The Journal of the International African Institute, Cambridge University Press, Volume 88, March 2018

Hine, Christine. Virtual Ethnography. London, Thousand Oaks, New Delhi:SAGE Publications, 2000

Michael J, Rosenfeld.. "Marriage, Choice, and Couplehood in the Age of the Internet." Sociological Science 4, p. 490-510. June 2017

Nasrullah, Teori dan Riset Media Siber (Cybermedia), Jakarta : Kencana Prenada Media 2014

Norman K. Denzin dan Yvonna S. Lincoln. Handbook of Qualitative Research. London : SAGE. 2011

Nugroho, Agoeng. Teknologi Komunikasi. Cetakan Ke-1. Yogyakarta: Graha Ilmu.2010

Pambayun, Ellys Lestari, One Stop Research Qualitative Methodology in Communication. Jakarta : Lentera Cendekia,2013

Polkosky, Melanie D. Understanding Social Media from the Media Ecological Perspective dalam

Konijn,Elly A., Utz, Sonja., Tanis, Martin, and Barnes, Susan B. Mediated Interpersonal Communication. New York: Routledge (396), 2008

Sari, Fhika Adina. "Gaya Pacaran Mahasiswa-Mahasiswi Santri Pondok Pesantren di Yogyakarta". Jurnal Sosiologi Pendidikan I. Universitas Negeri Yogyakarta. 2016

Severin, Werner J. \& James. W. Tankard, Jr. 2001. Communication Theories:Origins, Methods, and Use in Mass Media. USA. Addison Wesley Longman. Inc , 2001

Shang, Rang-An, Yu-Chen Chen, \& Je-Wei Chang, "Individual Attachment Style, Selfdisclosure, and How People Use Social Network", Multidisciplinary Social Networks Research in Communications in Computer and Information Science (CCIS), Volume 540, p. 49, August 2017

Imagefromhttp://www.flickr.com/photos/34207237@N04/4315865952/BSEO2010, http://www.forumkami.net/internet/143508-internet-ubah

http://id.shvoong.com/social-sciences/education/2270206-komunikasi-internet-danpenelitian -kualitatif/\#ixzz1z6uHUUQY

https://ekspresionline.com/2019/05/18/relasi-romantis-maya-dan-ilusi-cinta-yang-nihil/

Yulia Lisnawati https://www.liputan6.com/citizen6/read/4173803/studi-pasangan-yangbertemu-lewat-situs-kencan-diklaim-lebih-langgeng 07 Februari 2020 